\title{
Comparison of $0.5 \%$ Ropivacaine with $0.5 \%$ Ropivacaine and Magnesium sulphate in supraclavicular brachial plexus block for forelimb and hand surgeries
}

\author{
Taneja P. ${ }^{1}$, Singh M. ${ }^{2}$, Singh B. ${ }^{3}$, Attri J.P. ${ }^{4}$ \\ ${ }^{1}$ Dr Parvez Taneja, Assistant Professor, Department of Anesthesia, PIMS, Jalandhar, Punjab, India, ${ }^{2}$ Dr. Manjit Singh, \\ Anaesthesia, Associate Professor, Department of Anaesthesia, GMC Amritsar. India, ${ }^{3}$ Dr Balwinderjit Singh, Professor, \\ Department of Anesthesia, PIMS, Jalandhar, Punjab, India, ${ }^{4}$ Dr Joginder Pal Attri, Anaesthesia, Associate Professor, \\ Department of Anaesthesia, GMC Amritsar. India
}

Corresponding Author: Dr. Manjit Singh, Assistant Professor, Department of Anaesthesia, GMC Amritsar, India. Email: drjpattri@gmail.com

\begin{abstract}
Objectives: Supraclavicular Brachial Plexus is commonly used for forelimb and hand surgeries. A lot of research is going on to increase the duration of sensory and motor blockade by the addition of adjuvants with the local anesthetics. We evaluated the effect of adding magnesium sulphate to ropivacaine for supraclavicular brachial plexus blockade. Our primary parameters were the onset and duration of sensory and motor block and duration of analgesia. Methods: 60 patients posted for elective forearm and hand surgeries under supraclavicular brachial plexus block were divided into two equal groups (Group RM and RN) in a double blind fashion. In Group RM 30ml 0.5\% ropivacaine plus $150 \mathrm{mg}$ magnesium sulphate in ( $1 \mathrm{ml} 0.9 \%$ saline) and in group $\mathrm{RN} 1 \mathrm{ml}$ of normal saline was added to ropivacaine. Results: Both the groups have similar demographic profile and time of onset of senory and motor block but the duration of senory and motor blockade and duration of analgesia were significantly longer in RM group than RN group. Intraoperative hemodynamics were compareable amoung two groups and no considerable side effects were noted in both the groups. Conclusion: It can be concluded from our study that by addition of magnesium sulphate to local anesthetics in supraclavicular brachial plexus block may increase the duration of senory and motor blockade and duration of analgesia with no appreciable side effects, however duration of onset of sensory and motor blockade was more in magnesium sulphate group.
\end{abstract}

Key words: Supraclavicular brachial plexus block, Ropivacaine, Magnesium sulphate.

\section{Introduction}

Brachial plexus block provide a useful alternative to general anesthesia for upper limb surgery. It results in obtaining ideal operating conditions by producing complete muscular relaxation and stable intra-operative hemodynamics. Regional Anesthesia has particular importance in the orthopedic surgery than general anaesthesia due to better preservation of pharyngeal and laryngeal reflexes results in decreasing the risk of aspiration[1], decreased stress response in compromised patients and avoidance of difficult intubation [2]. Regional Anaesthesia also results in better postoperative analgesia without undue sedation and

Manuscript received: $20^{\text {th }}$ February 2018

Reviewed: $27^{\text {th }}$ February 2018

Author Corrected: $05^{\text {th }}$ March 2018

Accepted for Publication: $13^{\text {rd }}$ March 2018 facilitating early mobilization and discharge from the hospital.

Supra clavicular approach is commonly used for brachial plexus block because of its ease, reliability and high success rate. Moreover, this approach doesn't results in sparing of musculocutaneous or axillary nerves. Ropivacaine is a newer long acting amide local anesthetic having improved safety profile as compared to bupivacaine[3]. Ropivacaine has several other advantages namely to produce differential blockade with less motor blockade along with reduced cardiovascular and neurological toxicity. Local anesthetics alone for supraclavicular brachial plexus block provide ideal operative conditions but have 


\section{Original Research Article}

shorter duration of postoperative analgesia. So various adjuvants like opioids [4], clonidine [5] and dexamethasone [6] were added to local anesthetics to prolong the duration and intensity of brachial plexus block but the results were equivocal.

Magnesium[7] is second most intracellular cation present in the body in abundant quantities after potassium. It blocks competitively the entry of calcium in presynaptic nerve endings leading to reduced release of acetylcholine from nerve endings and can produce similar effects like calcium channel blockers. Magnesium also antagonize NMDA (N-methyl Daspartate ) receptors and thereby augment antinociceptive effect. Many authors in their studies have demonstrated the decreased requirement of anaesthetics during general anesthesia and postoperative analgesic consumption after magnesium administration $[8,9,10]$. Magnesium also results in decreased postoperative opioid consumption when administred through epidural route [11]. so due to these analgesic properties it can be tried as an adjuvant with local anesthetics to prolong the duration and intensity of brachial plexus block.

Hence our study was designed to test the hypothesis that magnesium if added as an adjuvant to ropivacaine while administering supraclavicular brachial plexus block may enhance the duration of analgesia, duration of sensory and motor block.

\section{Aims and Objectives}

The primary aim of our study was to compare:

1. The efficacy and clinical characteristics of ropivacaine $0.5 \%$ plus magnesium sulphate and ropivacaine $0.5 \%$ in supraclavicular brachial plexus block posted for forearm and hand surgery.

2. To note the onset and duration of sensory and motor block in both the groups

The secondary aim of our study was to see the effects of these drugs on haemodynamics and complications if any.

\section{Material and Methods}

This study was conducted in department of anesthesia of one of the leading medical college in Punjab. The present study was done on 60 cases of either sex of American Society of Anesthesiologists (ASA) I or II between age group of 18 and 50 years, weighing between 40 to 60 kilograms, scheduled for forarm and hand surgeries of one hour duration under supraclavicular brachial plexus block after approval by ethical committee.

A detailed history was taken and the patients were thoroughly examined on the previous day before the surgery. The procedure to be performed was explained to each patient one day before the day of operation during pre anesthetic evaluation.

Exclusion Criteria: History of respiratory, cardiac, hepatic or renal disease, convulsions, pregnant women. Patient with the history of bleeding disorders, local infection at the site of injection, anomalies of neck and shoulder, fracture clavicle, patients sensitive or allergic to ropivacaine and other local anesthetics..

BP and Pulse was measured in preanesthesia room, intravenous line was established and the patients was premedicated with Inj. glycopyrollate $0.2 \mathrm{mg} . \mathrm{kg}^{-1}$ of body weight intramuscularly half an hour before performing the block. Patient was shifted to operation theatre and monitor was attached. Inj. midazolam 0.1 mg.kg- ${ }^{-}$of body weight i.v was given before administering brachial plexus block. The patients were randomly and equally divided into two groups of 30 each. The group RM (Ropivacaine with magnesium sulphate) patients was given $30 \mathrm{ml}$ of $0.5 \%$ ropivacaine plus $150 \mathrm{mg} \mathrm{MgSo}_{4}$ (in $1 \mathrm{ml} 0.9 \%$ normal saline) while Group RN (ropivacaine plus normal saline) patients received $30 \mathrm{ml}$ of $0.5 \%$ ropivacaine plus $1 \mathrm{ml} 0.9 \%$ normal saline. After turning the head to opposite side, painting and draping of the supraclavicular region was done. The supraclavicular block was be performed by classical approach with a 23 gauge $4 \mathrm{~cm}$ long needle. The neurovascular bundle was located with peripheral nerve locator and the drug was injected on obtaining parasthesia after negative aspiration for blood.

During surgery pulse, systolic blood pressure, diastolic blood presure, oxygen saturation and ECG were monitered. Pulse, systolic blood presure, diastolic blood presure were recorded every 15 mins till the end of surgery. Oxygen was routinely administered via oxygen face mask at the rate of 4 litre per min. Maximum duration of all the surgery was upto 60- 90 mins.

Sensory blockade was assessed by 3 point sensory score:

- 0-Sharp pain on pinprick,

- 1-Touch sensation on pinprick,

- 2-Not even touch sensation on pinprick.

Onset of sensory blockade was taken as the time between injection and the complete ablation of pinprick 


\section{Original Research Article}

test (sensory score-2). Duration of sensory block will be defined as the time from complete block to return of the parasthesia (sensory score-0). If a sensory score of 2 was not achieved even after 45 minutes or if there was sparing in any segment, the sensory analgesia was deemed to be not satisfactory and these patients were excluded from the study. Complications of brachial plexus block and side effects of local anesthetics used were also noted.

Motor blockade was also assessed by a 3 point motor score described by Bromage:

- 0-Full flexion and full extension of elbow, wrist and fingers,

- 1-Ability to move fingers only

- 2-Inability to move fingers.

Onset of motor blockade was considered as the time from performance of block to the time when a complete inability to move fingers (score-2) was achieved. Duration of motor blockade was considered as time from complete motor blockade to the restoration of full flexion and extension of elbow, wrist and fingers (score$0)$.

\section{Results}

There was no statistical significant difference in age, weight $\&$ sex distribution between two groups

Onset and duration of Sensory and Motor Block- As Table 1 shows, mean duration of onset of sensory block in ropivacaine with $\mathrm{MgSo} 4$ group was $6.5 \pm 0.89 \mathrm{mins}$ and in ropivacaine with normal saline group was $5.5 \pm 0.65$ mins. Mean duration of onset of motor block in ropivacaine with $\mathrm{MgSo}_{4}$ was $14.3 \pm 2.64$ mins and in ropivacaine with normal saline group was12.4 \pm 2.06 . but on inter group comparison there was no statistical significant difference in onset of sensory block and onset of motor block between two Groups ( $\mathrm{p}>0.05)$.

Table-1: Onset and duration of Sensory and Motor Block in two Groups (min) (Mean \pm SD)

\begin{tabular}{|l|l|l|l|}
\hline Variables & $\begin{array}{l}\text { Group RM (Ropivacaine } \\
\left.\text { plus } \mathbf{M g S o}_{4}\right)\end{array}$ & $\begin{array}{l}\text { Group RN (Ropivacaine plus } \\
\text { normal saline) }\end{array}$ & p-value \\
\hline Onset of sensory block & $5.5 \pm 0.89$ & $6.5 \pm 0.65$ & $>0.05$ \\
\hline Onset of motor block & $14.3 \pm 2.64$ & $12.4 \pm 2.06$ & $>0.05$ \\
\hline $\begin{array}{l}\text { Duration of sensory } \\
\text { block }\end{array}$ & $420 \pm 30.25$ & $290 \pm 26.95$ & $<0.05$ \\
\hline $\begin{array}{l}\text { Duration of motor } \\
\text { block }\end{array}$ & $350 \pm 15.25$ & $236 \pm 20.06$ & $<0.05$ \\
\hline
\end{tabular}

Mean duration of sensory block in ropivacaine with $\mathrm{MgSo}_{4}$ group was $420 \pm 30.25$ mins and in ropivacaine with normal saline group was $290 \pm 26.95$ mins. Mean duration of motor block in ropivacaine with $\mathrm{MgSo}_{4}$ group was $350 \pm 15.25$ 
Original Research Article

mins and in ropivacaine with normal saline group was $236 \pm 20.06$. but on inter group comparison there was statistical significant difference in duration of sensory blockade and motor blockade $(\mathrm{p}<0.05)$.

Intra-operative Parameters- There was no statistical significant difference in intra-operative parameters namely pulse, systolic blood pressure and diastolic blood pressure between two groups ( $\mathrm{p}>0.05)$.

Duration of Analgesia- As fig.1 shows, duration of Analgesia in Group RM (Ropivacaine plus $\mathrm{MgSo}_{4}$ ) was $440 \pm 18.2$ mins and in Group RM (Ropivacaine plus normal saline) was $310 \pm 20.3$ mins and data was statistically significant ( $\mathrm{p}<$ $0.05)$.

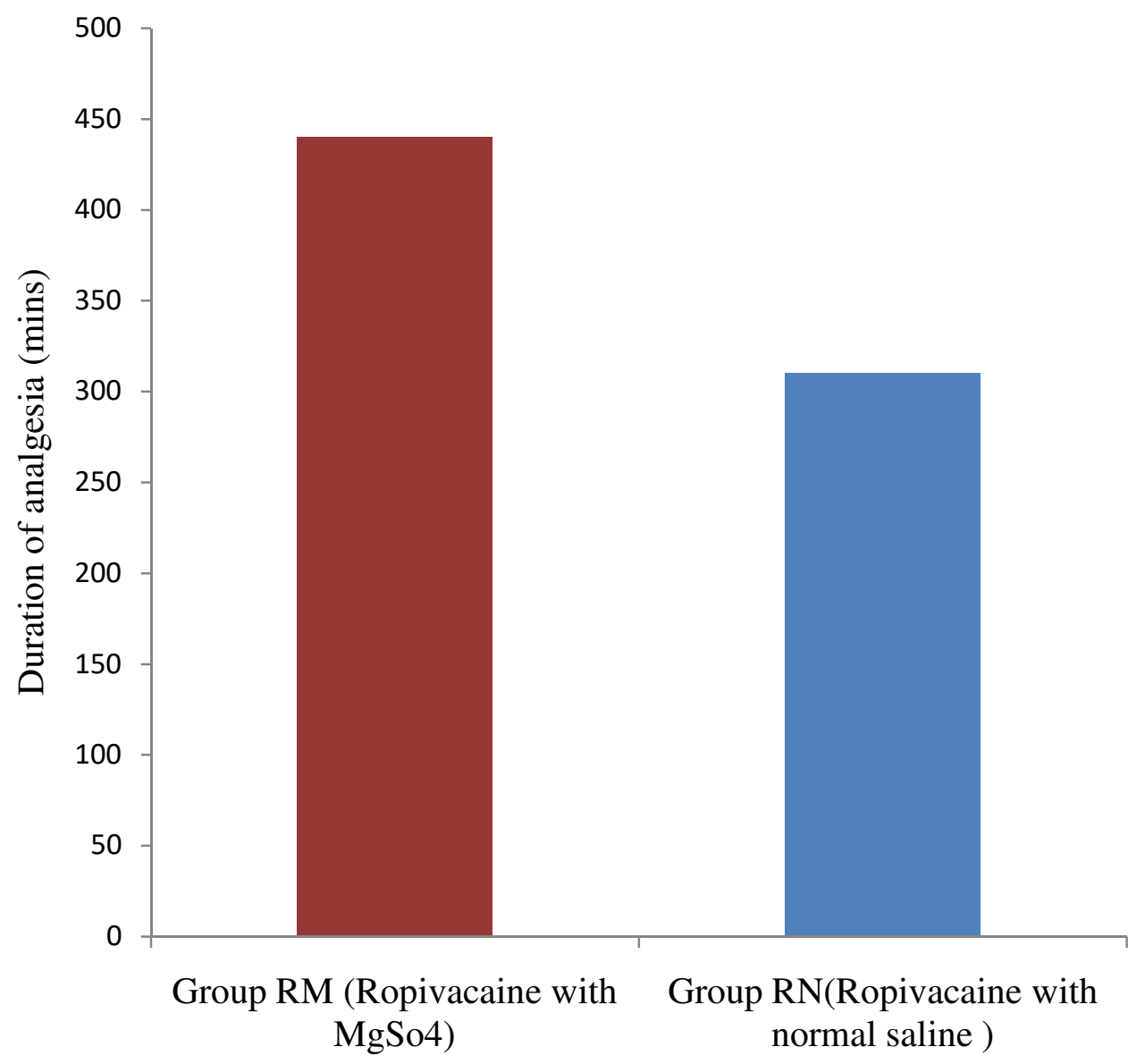

Fig-1: Duration of Analgesia between two Groups (mins)

Comparison of Complications- In our study, 3 patients had incidence of nausea, 5 patients had hypotension in Ropivacaine plus $\mathrm{MgSo}_{4}$ group as compared to 2 patients had incidence of nausea and 3 had hypotension in Ropivacaine plus normal saline group after 30 mins of administration of block but the difference was statistically insignificant. ( $>0.05$ ) (Table 2).

Table-2: Comparison of Complications in two Groups

\begin{tabular}{|l|l|l|}
\hline Complication & Group RM (Ropivacaine plus $\left.\mathbf{M g S o}_{4}\right)$ & $\begin{array}{l}\text { Group RM (Ropivacaine plus } \\
\text { normal saline) }\end{array}$ \\
\hline Nausea & 3 & 2 \\
\hline Hypotension & 5 & 3 \\
\hline
\end{tabular}




\section{Discussion}

In our prospective randomised clinically study we have compared 30 patients (Group RM) $30 \mathrm{ml}$ of $0.5 \%$ Ropivacaine plus $150 \mathrm{mg} \mathrm{MgSo}_{4}$ (in $1 \mathrm{ml} 0.9 \%$ normal saline) Versus 30 patients of (Group RN) $30 \mathrm{ml} 0.5 \%$ ropivacaine with $1 \mathrm{ml}$ normal saline. There was no statistical significant difference regarding age, weight and sex distribution between two groups.

The onset of sensory block in Group RM was 6.5 mins while in Group RN was 5.5 mins and the onset of motor blockade in Group RM was 14.3 mins and in Group RN was 12.4 mins. Although Sensory onset and motor onset were little delayed in group RM than in group $\mathrm{RN}$ but there was no statistical significant difference between two groups $(\mathrm{p}>0.05)$.

Khezri et al[12], Malleeswaran et al[13] and Ekmecki et al[14] also observed similar results while performing femoral nerve block found significantly delayed onset of sensory block in the levobupivacaine plus magnesium group than in the levobupivacaine group though it was statistically insignificant.

In our study, duration of sensory block was $(420 \pm 30.25$ mins in RM group and $290 \pm 26.95$ mins in $\mathrm{RN}$ group) significantly higher in the magnesium group than normal saline group $(\mathrm{p}<0.05)$.

The duration of motor block was $(350 \pm 15.25$ mins in $\mathrm{RM}$ group and $236 \pm 20.06$ mins in $\mathrm{RN}$ group) also significantly higher in magnesium group than normal saline group $(\mathrm{p}<0.05)$. Malleeswaran et al[12], Ekmekci et al[14] and Lee et al[15] also found similar results in their studies .

Total duration of analgesia in our study was (440 \pm 18.2 mins in RM group and $310 \pm 20.3$ mins in $\mathrm{RN}$ group) significantly higher in ropivacaine with magnesium group than ropivacaine with normal saline group.

Our findings were correlated to Malleeswaran etal[12] who found total duration of analgesia after interscalene brachial plexus block with bupivacaine and bupivacaine plus magnesium sulphate were $10.6 \mathrm{~h}$ and $11.6 \mathrm{~h}$ respectively.

Regarding complication, only three patients in RM group and two patients in RN group had nausea which was easily managed by only increasing the fluid transfusion rate and no active intervention was required. Hypotension occured only in five patients in RM group and two patients in RN group and they were managed by only increasing the rate of intravenous fluids except one patient required intravenous mephenteramine sulphate $5 \mathrm{mg}$. on intergroup comparison for both nausea and hypotension data was statistically insignificant $(\mathrm{p}>0.05)$.

Choi et al[16] also found similar complications (nausea, hypotension) in their study and the difference between magnesium group and normal saline group was statistically insignificant $(\mathrm{p}>0.05)$.

Several mechanisms of actions have been advocated to explain the analgesic effect of magnesium. The analgesic activity of Magnesium is chiefly exerted by NMDA receptor antagonism in a noncompetitive manner and at the same time by blocking competitively the entry of calcium in presynaptic endings leading to decreased release of acetylcholine[17,18].

This also results in reduced post synaptic activity of slow conducting unmyelinated $\mathrm{C}$-fibers which are chiefly afferent fibers conveying input signals from periphery to Central Nervous System[19,20].

\section{Conclusion}

We conclude that addition of $150 \mathrm{mg}$ Magnesium sulphate to ropivacaine $0.5 \%$ solution in supraclavicular brachial plexus block prolongs the duration of sensory, motor blockade and duration of analgesia but results in slight delay in the onset time of sensory and motor blockade.

So we recommend adding Magnesium sulphate as adjuvant to ropivacaine in brachial plexus block for upper limb surgeries.

\section{Contribution by Authors}

\section{Detail contribution is as mentioned below:}




\begin{tabular}{|l|l|l|l|l|}
\hline- & Contributor 1 & Contributor 2 & $\begin{array}{l}\text { Contributor 3 } \\
\text { and 4 }\end{array}$ \\
\hline Concepts & Yes & Yes & No \\
\hline Design & Yes & Yes & No \\
\hline Definition of intellectual content & Yes & Yes & No \\
\hline Literature search & Yes & Yes & No \\
\hline Clinical studies & Yes & Yes & No \\
\hline Experimental studies & Yes & Yes & No \\
\hline Data acquisition & Yes & Yes & No & No \\
\hline Data analysis & Yes & Yes & & No \\
\hline Statistical analysis & Yes & Yes & & Yes \\
\hline Manuscript preparation & Yes & No & & Yes \\
\hline Manuscript editing & No & No & Yes \\
\hline Manuscript review & Yes & Yes & Yes & No \\
\hline Guarantor & & & \\
\hline
\end{tabular}

Funding: Nil, Conflict of interest: None

Permission of IRB: Yes

\section{References}

1. Mckenzie PJ, Loach AB. Local anaesthesia for orthopedic surgery. Br J Anaesth 1986;58:779-89.

2. Khanduri KC. Regional Anaesthesia Techniques for Orthopaedic Surgery. Med J Armed Forces India. 2008 Apr;64(2):108-10. doi: 10.1016/S0377-1237(08)800482. Epub $2011 \mathrm{Jul} 21$.

3. Klein SM, Greengrass RA, Steele SM, D'Ercole FJ, Speer KP, Gleason DH, DeLong ER, Warner DS. A comparison of $0.5 \%$ bupivacaine, $0.5 \%$ ropivacaine, and $0.75 \%$ ropivacaine for interscalene brachial plexus block. Anesth Analg. 1998 Dec;87(6):1316-9.

4. Bazin JE, Massoni C, Groslier D, Fenies V, Bittar M, Schoeffler P. [Brachial plexus block: effect of the addition of sufentanil to local anesthetic mixture on postoperative analgesia duration]. Ann Fr Anesth Reanim. 1997;16(1):9-13.

5. Kohli S, Kaur M, Sahoo S, Vajifdar H, Kohli P. Brachial plexus block: Comparison of two different doses of clonidine added to bupivacaine. J Anaesthesiol Clin Pharmacol 2013;29:491-5. doi: 10.4103/09709185.119147.

6. Yadav RK, Sah BP, Kumar P, Singh SN. Effectiveness of addition of neostigmine or dexamethasone to local anaesthetic in providing perioperative analgesia for brachial plexus block: A prospective, randomized, double blinded, controlled study. Kathmandu Univ Med J (KUMJ). 2008 JulSep;6(23):302-9.

7. Sirvinskas E, Laurinaitis R. [Use of magnesium sulfate in anesthesiology]. Medicina (Kaunas). 2002;38(7):695-8.

8. Telci L, Esen F, Akcora D, Erden T, Canbolat AT, Akpir K. Evaluation of effects of magnesium sulphate in reducing intraoperative anaesthetic requirements. $\mathrm{Br}$ J Anaesth. 2002 Oct;89(4):594-8.

9. Koinig H, Wallner T, Marhofer P, Andel H, Hörauf $\mathrm{K}$, Mayer N. Magnesium sulfate reduces intra- and postoperative analgesic requirements. Anesth Analg. 1998 Jul;87(1):206-10. 


\section{Original Research Article}

10. Panda NB, Bharti N, Prasad S. Minimal effective dose of magnesium sulfate for attenuation of intubation response in hypertensive patient. J Clin Anesth 2013;25:92-7. doi: 10.1016/j.jclinane.2012.06.016. Epub 2013 Jan 17.

11. Agrawal A, Agrawal S, Payal YS. Effect of continuous magnesium sulfate infusion on spinal block characteristics: A prospective study. Saudi J Anaesth 2014;8:78-82. doi: 10.4103/1658-354X.125945.

12. Khezri MB, Yaghobi S, Hajikhani M, Asefzadeh S. Comparison of postoperative analgesic effect of intrathecal magnesium and fentanyl added to bupivacaine in patients undergoing lower limb orthopedic surgery. Acta Anaesthesiol Taiwan. 2012 Mar;50(1):19-24. doi: 10.1016/j.aat.2012.03.001. Epub 2012 Mar 31.

13. Malleeswaran S, Panda N, Mathew P, Bagga R. A randomised study of magnesium sulphate as an adjuvant to intrathecal bupivacaine in patients with mild preeclampsia undergoing caesarean section. Int J Obstet Anesth. $2010 \quad$ Apr;19(2):161-6. doi: 10.1016/j.ijoa.2009.08.007. Epub 2010 Feb 18.

14. Ekmekci P, Bengisun ZK, Akan B, Kazbek BK, Ozkan KS, Suer AH. The effect of magnesium added to levobupivacaine for femoral nerve block on postoperative analgesia in patients undergoing ACL reconstruction.Knee Surg Sports Traumatol Arthrosc. 2013 May;21(5):1119-24. doi: 10.1007/s00167-0122093-4. Epub 2012 Jun 14.
15. Lee AR, Yi HW, Chung IS, Ko JS, Ahn HJ, Gwak MS, Choi DH, Choi SJ. Magnesium added to bupivacaine prolongs the duration of analgesia after interscalene nerve block. Can J Anaesth. 2012 Jan;59(1):21-7. doi: 10.1007/s12630-011-9604-5. Epub 2011 Oct 20.

16. Choi IG, Choi YS, Kim YH, Min JH, Chae YK, Lee YK, et al. The Effects of Postoperative Brachial Plexus Block Using MgSo4 on the Postoperative Pain after Upper Extremity Surgery. Korean J Pain 2011;24:15863. doi: 10.3344/kjp.2011.24.3.158.

17. Woolf CJ, Thompson SW. The induction and maintenance of central sensitization is dependent on $\mathrm{N}$ methyl-D-aspartic acid receptor activation; implications for the treatment of post-injury pain hypersensitivity states. Pain. 1991 Mar;44(3):293-9.

18. Ascher P, Nowak L. Electrophysiological studies of NMDA receptors. Trends Neurosci 1987;10:284-8.

19. Woolf CJ, Chong MS. Preemptive analgesia-treating postoperative pain by preventing the establishment of central sensitization. Anesth Analg. 1993 Aug;77(2):362-79.

20. Liu HT, Hollmann MW, Liu WH, Hoenemann CW, Durieux ME. Modulation of NMDA receptor function by ketamine and magnesium: Part I. Anesth Analg. 2001 May;92(5):1173-81.

\section{How to cite this article?}

Taneja P., Singh M., Singh B., Attri J.P. Comparison of $0.5 \%$ Ropivacaine with 0.5\% Ropivacaine and Magnesium sulphate in supraclavicular brachial plexus block for forelimb and hand surgeries. Int J Med Res Rev 2018;6 (03):136142. doi:10.17511/ijmrr. 2018.i03.02. 